\title{
FAKTOR-FAKTOR YANG MEMPENGARUHI PERILAKU PENCEGAHAN HIV/AIDS PADA IBU RUMAH TANGGA
}

\author{
Rahmah Fitrianingsih $^{1}$, Yulia Irvani Dewi ${ }^{2}$, Rismadefi Woferst ${ }^{3}$ \\ Program Studi Ilmu Keperawatan \\ Universitas Riau \\ Email: rahmah03 fitrianingsih@yahoo.com
}

\begin{abstract}
Abstrak
Acquired Immune Deficiency Syndrome (AIDS) merupakan sekumpulan gejala penyakit yang disebabkan oleh virus yang mudah menular dan mematikan juga merusak sistem kekebalan tubuh.Kelompok yang rentan adalah IRT. Hal ini disebabkan perilaku pencegahan yang masih rendah. Penelitian ini bertujuan untuk menganalisis faktor-faktor yang mempengaruhi perilaku pencegahan HIV/AIDS dengan desain penelitian deskriptif korelasi dengan pendekatan cross sectional. Sampel penelitian sebanyak 100 orang responden yang diambil berdasarkan kriteria inklusi menggunakan teknik cluster sampling. Instrumen yang digunakan adalah kuesioner yang telah diuji validitas dan reabilitas. Analisis yang digunakan adalah analisis univariat untuk mengetahui distribusi frekuensi dan analisa bivariat menggunakan uji Chi Square untuk variabel faktor-faktor yang mempengaruhi perilaku pencegahan HIV/AIDS. Hasil penelitian analisis univariat menunjukkan mayoritas IRT berada dalam rentang usia 26-35 tahun (37\%), beragama Islam (94\%), pekerjaan wiraswasta (46\%), istri yang tidak melakukan pemeriksaan HIV/AIDS (88\%), dan suami yang tidak melakukan pemeriksaan HIV/AIDS (95\%). Hasil analisis bivariat menunjukkan ada hubungan pengetahuan ( $p$ value 0.023$)$ dan pendidikan ( $p$ value 0.004$)$ terhadap perilaku pencegahan. Variabel yang tidak berhubungan adalah sikap ( $p$ value 0.199 ), ekonomi ( $p$ value 0.641$)$ dan lama menikah ( $p$ value 0.275 ) terhadap perilaku pencegahan HIV/AIDS. Berdasarkan hasil penelitian ini, disarankan IRT lebih peduli terhadap kesehatannya dengan melakukan upaya pencegahan HIV/AIDS.
\end{abstract}

Kata Kunci : ekonomi, HIV/AIDS, lama menikah, pencegahan, pendidikan, pengetahuan, sikap

Abstract

Acquired Immune Deficiency Syndrome (AIDS) are symptoms caused by the Human Immune Virus (HIV) is contagious and deadly also damage the immune system. The vulnerable group is housewife because the prevention behavior was low. This study aims to analyze the factors that influence HIV/AIDS prevention behavior with descriptive correlation research design with cross sectional approach. The sample was 100 respondents taken based on the inclusion criteria using cluster sampling technique. The instrument used is a questionnaire that has been tested for validity and reliability. The analisys used univariate analisys to know the frequency distribution and bivariate analysis using Chi Square test for the variable of factors influencing HIV/AIDS prevention behavior. The results of the univariate anailsys showed the majority of housewife were in the 26-35 years age range (37\%), Moeslim (94\%), entrepreneur (46\%), the wife did not conduct HIV/AIDS testing (88\%), and The husband did not conduct HIV/AIDS testing (95\%). The result of bivariate analysis shows that there is knowledge relation ( $p$ value 0.023) and education ( $p$ value 0.004) to HIV/AIDS preventive behavior. Unrelated variable are attitude ( $p$ value 0.199), economy ( $p$ value 0.641) and marriage length ( $p$ value 0.275) to HIV/AIDS prevention behavior. Based on the results of this study, it is suggested housewife more concerned about health by doing HIV/AIDS prevention efforts.

Keywords : attitude,economy,education,HIV/AIDS, long marriage, knowledge, prevention

\section{PENDAHULUAN}

Permasalahan Human Immuno Virus (HIV) dan Aquired Immunodefisiency

Syndrome (AIDS) sampai saat ini masih merupakan masalah kesehatan dunia karena setiap tahun insidennya terus meningkat. Berdasarkan laporan World Health Organization (WHO) tahun 2015 tercatat 36,7 juta orang di dunia yang hidup dengan HIV dan sekitar 2,1 juta orang ditemukan kasus 
Rahmah Fitrianingsih ${ }^{1}$, Yulia Irvani Dewi ${ }^{2}$, Rismadefi Woferst ${ }^{3}$,Faktor-Faktor Yang Mempengaruhi Perilaku Pencegahan HIV/AIDS Pada Ibu Rumah Tangga

baru terinfeksi HIV. Di Asia tercatat sebanyak

5,1 juta kasus infeksi HIV dengan kasus terbanyak di negara India yakni 2,1 juta kasus, sedangkan Indonesia menempati urutan ke-3 terbanyak di Asia yaitu 610.000 kasus. Lebih dari 1,7 juta perempuan di Asia hidup dengan HIV, dan 90\% tertular dari suami atau pasangan seksual. Perempuan yang rentan tertular adalah Ibu Rumah Tangga (IRT) (UNAIDS, 2013).

Berdasarkan laporan Direktorat Jenderal Pengendalian Penyakit dan Penyehatan Lingkungan (Ditjen PP dan PL) Kemenkes tahun 2016, jumlah kumulatif sampai Maret sebanyak 191.073 penderita HIV dan 77.940 kasus AIDS. Peningkatan kasus HIV/AIDS juga terjadi di Provinsi Riau dengan urutan ke-15 mencapai 4.413 kasus. Kota Pekanbaru merupakan wilayah dengan insiden HIV/AIDS tertinggi. Data tahun 2014 sebanyak 136 HIV kasus dan 111 kasus AIDS, tahun 2015 sebanyak 241 kasus HIV dan 168 kasus AIDS, dan tahun 2016 sebanyak 261 kasus HIV dan 187 kasus AIDS, dan angka kematian sebanyak 161 kasus. Berdasarkan jenis kelamin, HIV banyak ditemukan pada laki-laki yaitu $64 \%$ dan perempuan $36 \%$, sedangkan AIDS pada laki-laki sebesar 73\% dan perempuan $27 \%$. Sebagian besar penderita HIV adalah heteroseksual yakni 825 kasus, kasus lainnya adalah biseksual sebanyak 183 kasus, homoseksual 68 kasus, Intravenous Drug User (IDU) 42 kasus, Mother To Child Transmission (MTCT) 39 kasus dan pemakaian tatto 2 kasus (Dinas Kesehatan
Kota Pekanbaru 2016). Berdasarkan golongan umur, penderita HIV/AIDS terbanyak ditemukan pada kelompok umur 20-49 tahun. Kelompok umur tersebut masuk kedalam kelompok umur produktif yang aktif secara seksual.

Data dari tahun 2005 sampai 2015 menunjukkan jumlah pengidap HIV/AIDS di Indonesia sebanyak 2.800 orang, lebih dari 80\% yang tertular HIV adalah IRT. Kondisi ini menunjukkan bahwa masalah HIV/AIDS sudah memasuki ranah keluarga. IRT merupakan seseorang yang sangat berisiko tinggi tertular HIV/AIDS karena dapat ditularkan oleh suami yang melakukan transaksi seksual yang tidak aman ketika diluar rumah. Pekerjaan suami yang rentan terinfeksi HIV/AIDS adalah mereka yang bekerja sebagai sopir antar kota atau antar provinsi, pekerja konstruksi seperti jalan, jembatan, bangunan, pelabuhan dan yang sejenisnya. Penelitian Kristawansari (2013) menyatakan $76,5 \%$ pengetahuan sopir truk masih dikategorikan rendah dan 94,1\% sikap sopir truk dalam perilaku pencegahan HIV/AIDS kurang baik.

Data dari Dinas Kesehatan Kota Pekanbaru tahun 2016 IRT berada di urutan ke-4 setelah PSK, wiraswata dan tenaga non profesional yaitu sebanyak 223 yang terkena HIV/AIDS. Penularan HIV dari laki-laki ke perempuan 2-4 kali lebih besar daripada perempuan ke laki-laki. Perempuan rentan terinfeksi HIV/AIDS karena rendahnya daya tawar dan negosiasi dalam berhubungan 
seksual. Kerentanan perempuan ini disebabkan faktor biologis, perempuan mempunyai selaput mukosa yang lebih luas sehingga mudah mengalami luka atau iritasi. Faktor lainnya adalah faktor ekonomi, stigma, diskriminasi, informasi, pendidikan, pengetahuan dan kesadaran. Dari segi ekonomi IRT sangat tergantung kepada suami yang menyebabkan istri tidak dapat menolak apapun kehendak dari suami, termasuk dalam hubungan seksual.

Faktor stigma dan diskriminasi, perempuan mengalami stigma ganda, yaitu sebagai perempuan yang cenderung disalahkan atas apa yang terjadi terhadap dirinya sendiri. Masyarakat menganggap semestinya perempuan dapat menjaga diri, suami, dan keluarganya sehingga tidak terinfeksi HIV/AIDS. Faktor informasi dan pendidikan perempuan jauh lebih rendah sehingga mereka tidak memiliki pengetahuan yang cukup mengenai kesehatan reproduksi, termasuk persoalan seputar HIV/AIDS dan pelayanan kesehatan yang menjadi hak mereka. Hal ini berdampak terhadap kurangnya pengetahuan dan kesadaran IRT tentang HIV/AIDS dan pencegahannya (Dalimonthe, 2011; Susanti, 2017).

Berbagai upaya pencegahan HIV/AIDS sudah dilakukan dengan proses edukasi dan promosi seperti penyuluhan, baik melalui media cetak, elektronik dan penyuluhan secara langsung. Namun upaya tersebut belum memberikan pemahaman kepada masyarakat terutama IRT tentang dampak HIV/AIDS bagi dirinya serta keluarga. Oleh sebab itu, upaya tersebut harus melibatkan secara langsung IRT dengan berbagai kegiatan seperti kegiatan PKK, mulai dari tingkat RT, RW, Kelurahan, Kecamatan hingga Kabupaten/Kota. Kegiatan tersebut bertujuan untuk merubah atau mengurangi perilaku yang beresiko terinfeksi HIV (Departemen Kesehatan RI, 2016).

Menurut WHO (2016), pencegahan HIV/AIDS bisa juga dilakukan dengan melakukan layanan sukarela tes HIV yang bertujuan untuk pencegahan HIV. Namun, masih sedikit IRT yang mau melakukan pemeriksaan. Berdasarkan hasil penelitian Umam, Dewi dan Elita (2011) menyatakan bahwa responden masih mempunyai motivasi yang rendah tentang program pelayanan pemeriksaan HIV/AIDS (VCT). Penelitian Tjan, Sitorus, Armanita, Wijayaningrum, Feby, dan Pusponegoro (2013) menyatakan bahwa tingkat pengetahuan masyarakat terhadap pencegahan HIV melalui pemeriksaan VCT masih sangat rendah. Penelitian Dewi dan Nauli (2016) menyatakan bahwa 70\% IRT tidak pernah melakukan tes HIV, 62\% memiliki pengetahuan rendah dan perilaku pencegahan buruk sebanyak $77 \%$. Hasil penelitian Wulandari, Dewi dan Karim (2013), di RW 5 Kelurahan Meranti Pandak Pekanbaru menunjukkan 68,2\% pengetahuan IRT tinggi tentang HIV/AIDS dan melakukan upaya yang baik terhadap pencegahan HIV/AIDS.

Menurut penelitian Oktarina, Hanafi dan Budisuar (2009), menjelaskan bahwa perempuan yang mempunyai tingkat 
Rahmah Fitrianingsih ${ }^{1}$, Yulia Irvani Dewi ${ }^{2}$, Rismadefi Woferst ${ }^{3}$,Faktor-Faktor Yang Mempengaruhi Perilaku Pencegahan HIV/AIDS Pada Ibu Rumah Tangga

pendidikan tinggi cenderung mempunyai pengetahuan yang lebih baik, begitu pula sebaliknya. Penelitian pendukung lainnya Abhinaja dan Astuti (2013) menyatakan bahwa pengetahuan, sikap IRT mengenai infeksi menular seksual termasuk HIV/AIDS serta perilaku pencegahannya di Denpasar dikategori cukup (54\%), dan sikap sedang $(67,8 \%)$. Penelitian lain menyebutkan bahwa 52,53\% IRT berpersepsi negatif tentang HIV/ AIDS, sedangkan sisanya $46,47 \%$ IRT berpersepsi positif tentang HIV/AIDS (Superi, 2013).

$\begin{array}{ccr}\text { Berdasarkan } & \text { studi } & \text { pendahuluan } \\ \text { didapatkan bahwa } & \text { wilayah } & \text { Puskesmas }\end{array}$ Tenayan Raya merupakan salah satu lokalisasi dimana pekerja seks komersial (PSK) tinggal dan bekerja. Dinas Kesehatan Kota Pekanbaru, mencatat kasus HIV/AIDS tertinggi adalah di Puskesmas Tenayan Raya yaitu 1264 kasus. Hasil wawancara dengan penanggung jawab program HIV/AIDS di Puskesmas Tenayan Raya mengatakan bahwa penyuluhan tentang HIV/AIDS sudah pernah dilakukan, namun kurang efektif dikarenakan antusias IRT menghadiri penyuluhan masih sangat kurang. Pemeriksaan HIV/AIDS hanya dilakukan pada perempuan hamil dan sudah menjadi program wajib Puskesmas, sedangkan IRT yang lain tidak mau melakukan pemeriksaan sukarela tersebut. Disamping itu adanya persepsi yang salah tentang pemeriksaan HIV/AIDS (VCT), dimana IRT menganggap bahwa VCT tersebut hanya untuk pekerja seksual atau perempuan "nakal". Hal ini sesuai dengan hasil wawancara dengan 7 orang IRT, 3 orang IRT mengatakan tidak tahu tentang HIV/AIDS dan 4 orang IRT mengatakan hanya mengetahui apa itu HIV/AIDS namun tidak tahu bagaimana pencegahan yang dapat dilakukan, serta IRT masih menganggap melakukan tes HIV/AIDS hanya untuk pekerja seksual.

\section{METODOLOGI PENELITIAN}

Penelitian ini dilaksanakan di wilayah kerja Puskesmas Tenayan Raya, kota Pekanbaru yang dimulai dari bulan Februari sampai bulan Juli 2017. Penelitian ini menggunakan desain deskriptif korelatif dengan pendekatan Cross Sectional.

Populasi dari penelitian ini adalah IRT diwilayah kerja Puskesmas Tenayan Raya. Pengambilan sampel menggunakan teknik cluster sampling dengan kriteria inklusi sebanyak 100 orang responden.

Alat pengumpulan data yang digunakan adalah kuesioner. Analissi data menggunakan analisis univariat dan bivariat. Analisis univariat mendeskripsikan karakteristik responden terkait umur, agama, pekerjaan suami, pemeriksaan HIV/AIDS suami, istri dan hasil pemeriksaan. Analisis bivariat digunakan untuk mengetahui apakah ada hubungan yang signifikan antara faktor pendidikan, pengetahuan, sikap, ekonomi dan lama menikah dengan perilaku pencegahan HIV/AIDS pada IRT. 


\section{HASIL PENELITIAN}

\section{Analisis univariat}

Distribusi berdasarkan karakteristik responden dijelaskan pada tabel 1 dibawah ini.

Tabel 1

Distribusi karakteristik responden

\begin{tabular}{|c|c|c|}
\hline Karakteristik & $\mathrm{n}$ & $\%$ \\
\hline \multicolumn{3}{|l|}{ Usia } \\
\hline Remaja akhir (17-25 tahun) & 12 & 12 \\
\hline Dewasa awal (26-35 tahun) & 37 & 37 \\
\hline Dewasa akhir (36-45 tahun) & 28 & 28 \\
\hline Lansia awal (46-55 tahun) & 21 & 21 \\
\hline Lansia akhir (56-65 tahun) & 2 & 2 \\
\hline \multicolumn{3}{|l|}{ Agama } \\
\hline Islam & 94 & 94 \\
\hline Kristen Protestan & 4 & 4 \\
\hline Katolik & 2 & 2 \\
\hline \multicolumn{3}{|l|}{ Pekerjaan suami } \\
\hline PNS & 19 & 19 \\
\hline Wiraswasta & 46 & 46 \\
\hline Petani & 22 & 22 \\
\hline Sopir & 2 & 2 \\
\hline Tukang & 4 & 4 \\
\hline Karyawan swasta & 7 & 7 \\
\hline \multicolumn{3}{|l|}{ Pemeriksaan HIV/AIDS istri } \\
\hline Ya & 12 & 12 \\
\hline Tidak & 88 & 88 \\
\hline \multicolumn{3}{|l|}{ Hasil pemeriksaan HIV/AIDS } \\
\hline istri & 0 & 0 \\
\hline Positif & 100 & 100 \\
\hline \multicolumn{3}{|c|}{ Negatif } \\
\hline \multicolumn{3}{|c|}{ Pemeriksaan HIV/AIDS suami } \\
\hline Ya & 5 & 5 \\
\hline Tidak & 95 & 95 \\
\hline \multicolumn{3}{|l|}{ Hasil pemeriksaan HIV/AIDS } \\
\hline suami & 1 & 1 \\
\hline Positif & 99 & 99 \\
\hline \multicolumn{3}{|l|}{ Negatif } \\
\hline Total & 100 & 100 \\
\hline
\end{tabular}

Tabel 1 menunjukkan bahwa kelompok umur terbanyak adalah dewasa awal (26-35 tahun) sebanyak 37 orang responden (37\%), dan mayoritas beragama Islam yaitu sebanyak 94 orang responden (94\%), mayoritas pekerjaan suami yaitu wiraswasta sebanyak 46 responden (46\%). Berdasarkan tabel 4 juga diketahui bahwa mayoritas istri tidak melakukan pemeriksaan HIV/AIDS sebanyak 88 responden responden ( $88 \%$ ), dan bagi yang melakukan pemeriksaan tes HIV/AIDS semua dinyatakan negatif (100\%). Berdasarkan pemeriksaan HIV/AIDS mayoritas suami, tidak melakukan pemeriksaan HIV/AIDS sebanyak 95 orang responden (95\%), dan bagi yang melakukan pemeriksaan HIV/AIDS 1 responden dinyatakan positif HIV/AIDS.

Tabel 2

Distribusi karakteristik responden berdasarkan pengetahuan

\begin{tabular}{lcc}
\hline Pengetahuan & Frekuensi (f) & Persentase (\%) \\
\hline Baik & 47 & 47 \\
Cukup & 40 & 40 \\
Kurang & 13 & 13 \\
\hline Total & 100 & 100 \\
\hline
\end{tabular}

Tabel 2 diketahui sebagian besar responden memiliki pengetahuan baik terhadap perilaku pencegahan HIV/AIDS yaitu sebanyak 47 orang (47\%).

Tabel 3

Distribusi karakteristik responden

berdasarkan pendidikan

\begin{tabular}{lcc}
\hline Pendidikan & Frekuensi (f) & Persentase (\%) \\
\hline Tinggi & 22 & 22 \\
Menengah & 36 & 36 \\
Rendah & 42 & 42 \\
\hline Total & 100 & 100 \\
\hline
\end{tabular}

Tabel 3 didapatkan sebagian besar responden memiliki pendidikan rendah yaitu sebanyak 42 orang responden (42\%).

Tabel 4

Distribusi karakteristik responden berdasarkan sikap

\begin{tabular}{|c|c|c|}
\hline Sikap & Frekuensi (f) & Persentase $(\%)$ \\
\hline Positif & 41 & 41 \\
\hline Negatif & 59 & 59 \\
\hline Total & 100 & 100 \\
\hline
\end{tabular}

Tabel 4 diatas, responden memiliki sikap yang hampir sama antara sikap positif dan negatif terhadap perilaku pencegahan 


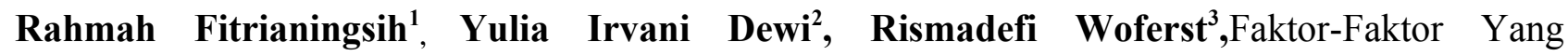
Mempengaruhi Perilaku Pencegahan HIV/AIDS Pada Ibu Rumah Tangga

HIV/AIDS sebanyak 59 orang (59\%) memiliki

sikap negatif.

Tabel 5

Distribusi karakteristik responden

berdasarkan lama menikah

\begin{tabular}{lcc}
\hline Lama menikah & $\begin{array}{c}\text { Frekuensi } \\
(\mathrm{f})\end{array}$ & $\begin{array}{c}\text { Persentase } \\
(\%)\end{array}$ \\
\hline $\begin{array}{l}\text { Pernikahan awal (1-10 } \\
\text { tahun) }\end{array}$ & 51 & 51 \\
$\begin{array}{l}\text { Pernikahan menengah (11- } \\
30 \text { tahun) }\end{array}$ & 44 & 44 \\
Pernikahan tua ( $\geq 30$ tahun) & 5 & 5 \\
\hline Total & 100 & 100 \\
\hline
\end{tabular}

Tabel 5 didapatkan sebagian besar responden telah menikah selama rentang 1-10 tahun (pernikahan awal) sebanyak 51 orang $(51 \%)$.

Tabel 6

Distribusi karakteristik responden

berdasarkan pendapatan

\begin{tabular}{lcc}
\hline Pendapatan & $\begin{array}{c}\text { Frekuensi } \\
(\mathrm{f})\end{array}$ & $\begin{array}{c}\text { Persentase } \\
(\%)\end{array}$ \\
\hline >UMR $(>2.352 .577)$ & 55 & 55 \\
$<$ UMR $(<2.352 .577)$ & 45 & 45 \\
& & \\
\hline Total & 100 & 100 \\
\hline
\end{tabular}

Tabel 6 didapatkan pendapatan responden hampir sama antara $>$ UMR dengan $<$ UMR terhadap perilaku pencegahan HIV/AIDS yani sebanyak 55 responden (55\%) dengan pendapatan $>$ UMR.

Tabel 7

Distribusi karakteristik responden berdasarkan perilaku pencegahan HIVIAIDS

\begin{tabular}{lcc}
\hline Perilaku pencegahan & Frekuensi (f) & $\begin{array}{c}\text { Persentase } \\
(\%)\end{array}$ \\
\hline Melakukan & 43 & 43 \\
Tidak melakukan & 57 & 57 \\
\hline Total & 100 & 100 \\
\hline
\end{tabular}

Tabel 7 didapatkan sebagian besar responden tidak melakukan perilaku pencegahan terhadap HIV/AIDS sebanyak 57 responden $(57 \%)$.

\section{Analisa Bivariat}

Tabel 8

Hubungan lama menikah dengan perilaku pencegahan HIV/AIDS

\begin{tabular}{|c|c|c|c|c|c|c|c|}
\hline \multirow{3}{*}{$\begin{array}{l}\text { Penge } \\
\text { tahuan }\end{array}$} & \multicolumn{4}{|c|}{ Perilaku pencegahan } & & & \multirow{3}{*}{$\begin{array}{c}p \\
\text { value }\end{array}$} \\
\hline & \multicolumn{2}{|c|}{$\begin{array}{l}\text { Melaku } \\
\text { kan }\end{array}$} & \multicolumn{2}{|c|}{$\begin{array}{c}\text { Tidak } \\
\text { melaku } \\
\text { kan }\end{array}$} & \multicolumn{2}{|c|}{ Total } & \\
\hline & $\mathrm{n}$ & $\%$ & $\mathrm{n}$ & $\%$ & $\mathrm{n}$ & $\%$ & \\
\hline Baik & 27 & 57,4 & 20 & 42,6 & 47 & 100 & \multirow{3}{*}{0,023} \\
\hline Cukup & 12 & 30,0 & 28 & 70,0 & 40 & 100 & \\
\hline Kurang & 4 & 30,8 & 9 & 69,2 & 13 & 100 & \\
\hline Total & 43 & 43 & 57 & 57 & 100 & 100 & \\
\hline
\end{tabular}

Tabel 8 menjelaskan bahwa dari 47 responden dengan pengetahuan baik yang melakukan pencegahan sebanyak 27 orang $(57,4 \%)$ dan responden yang tidak melakukan sebanyak 20 orang $(42,6 \%)$. Responden dengan pengetahuan cukup dari 40 orang responden yang melakukan upaya pencegahan sebanyak 12 orang $(30,0 \%)$ dan responden yang tidak melakukan pencegahan sebanyak 28 orang (70,0\%). Responden dengan pengetahuan kurang dari 13 orang yang melakukan pencegahan sebanyak 4 orang $(30,8 \%)$ dan yang tidak melakukan pencegahan sebanyak 9 orang $(69,2 \%)$. Hasil uji statistik Chi Square didapatkan $p$ value $=0,023$ yang berarti Ho ditolak dan dapat disimpulkan bahwa terdapat hubungan yang signifikan antara tingkat pengetahuan dengan perilaku pencegahan HIV/AIDS

Tabel 9

Hubungan pendidikan terhadap perilaku pencegahan HIV/AIDS pada IRT

\begin{tabular}{|c|c|c|c|c|}
\hline \multirow{3}{*}{$\begin{array}{l}\text { Pendidi } \\
\text { kan }\end{array}$} & \multicolumn{2}{|c|}{ Perilaku pencegahan } & \multirow[b]{2}{*}{ Total } & \multirow{3}{*}{$\begin{array}{c}p \\
\text { value }\end{array}$} \\
\hline & $\begin{array}{c}\text { Melaku } \\
\text { kan }\end{array}$ & $\begin{array}{c}\text { Tidak } \\
\text { melaku } \\
\text { kan }\end{array}$ & & \\
\hline & $\%$ & $\mathrm{n} \quad \%$ & $\%$ & \\
\hline
\end{tabular}




\begin{tabular}{lccccccc}
\hline Tinggi & 12 & 54,5 & 10 & 45,5 & 22 & 100 & \\
\cline { 1 - 6 } $\begin{array}{l}\text { Mene } \\
\text { ngah }\end{array}$ & 21 & 58,3 & 15 & 41,7 & 36 & 100 & 0,004 \\
\cline { 1 - 6 } Rendah & 10 & 23,8 & 32 & 76,2 & 42 & 100 & \\
\hline Total & 43 & 43 & 57 & 57 & 100 & 100 & \\
\hline
\end{tabular}

Tabel 9 menjelaskan bahwa dari 42 responden dengan pendidikan rendah yang melakukan pencegahan sebanyak 10 orang $(23,8 \%)$ dan responden yang tidak melakukan sebanyak 32 orang (76,2\%). Responden dengan pendidikan menengah dari 36 orang responden yang melakukan upaya pencegahan sebanyak 21 orang $(58,3 \%)$ dan responden yang tidak melakukan pencegahan sebanyak 15 orang (41,7\%). Responden dengan pendidikan tinggi dari 22 orang yang melakukan pencegahan sebanyak 12 orang (54,5\%) dan yang tidak melakukan pencegahan sebanyak 10 orang $(45,5 \%)$. Hasil uji statistik Chi Square didapatkan $p$ value $=0,004$ yang berarti Ho ditolak dan dapat disimpulkan bahwa terdapat hubungan yang signifikan antara tingkat pendidikan dengan perilaku pencegahan HIV/AIDS.

Tabel 10

Hubungan sikap terhadap perilaku pencegahan HIV/AIDS pada IRT

\begin{tabular}{|c|c|c|c|c|c|c|c|}
\hline \multirow{3}{*}{ Sikap } & \multicolumn{4}{|c|}{ Perilaku pencegahan } & \multirow{2}{*}{\multicolumn{2}{|c|}{ Total }} & \multirow{3}{*}{$\begin{array}{c}p \\
\text { value }\end{array}$} \\
\hline & \multicolumn{2}{|c|}{$\begin{array}{l}\text { Melaku } \\
\text { kan }\end{array}$} & \multicolumn{2}{|c|}{$\begin{array}{c}\text { Tidak } \\
\text { melaku } \\
\text { kan }\end{array}$} & & & \\
\hline & $\mathrm{n}$ & $\%$ & $\mathrm{n}$ & $\%$ & $\mathrm{n}$ & $\%$ & \\
\hline Positif & 14 & 34,1 & 27 & 65,9 & 41 & 100 & \\
\hline Negatif & 29 & 49,2 & 30 & 50,8 & 59 & 100 & 0,199 \\
\hline Total & 43 & 43 & 57 & 57 & 100 & 100 & \\
\hline
\end{tabular}

Tabel 10 menunjukkan bahwa dari 59 orang responden dengan sikap negatif yang tidak melakukan perilaku pencegahan sebanyak 30 orang $(50,8 \%)$ dan yang melakukan pencegahan sebanyak 29 orang
(49,2\%). Responden yang memilki sikap positif dari 41 orang yang tidak melakukan pencegahan 27 orang $(65,9 \%)$ dan yang melakukan pencegahan sebanyak 14 orang (34,1\%).Hasil uji statistik Chi Square didapatkan $p$ value=0,199 yang berarti Ho gagal ditolak dan dapat disimpulkan bahwa tidak ada hubungan yang signifikan antara sikap dengan perilaku pencegahan HIV/AIDS

Tabel 11

Hubungan pendapatan dengan perilaku pencegahan HIV/AIDS

\begin{tabular}{cccccccc}
\hline \multirow{2}{*}{$\begin{array}{c}\text { Penda } \\
\text { patan }\end{array}$} & \multicolumn{4}{c}{$\begin{array}{c}\text { Perilaku pencegahan } \\
\text { kan }\end{array}$} & $\begin{array}{c}\text { Tidak } \\
\text { melaku } \\
\text { kan }\end{array}$ & Total & \multirow{2}{*}{$\begin{array}{c}p \\
\text { value }\end{array}$} \\
\cline { 2 - 6 } & $\mathrm{n}$ & $\%$ & $\mathrm{n}$ & $\%$ & $\mathrm{n}$ & $\%$ & \\
\hline$>$ UMR & 22 & 40,0 & 33 & 60,0 & 55 & 100 & \\
\hline <UMR & 21 & 46,7 & 24 & 53,5 & 45 & 100 & 0,641 \\
\hline Total & 43 & 43 & 57 & 57 & 100 & 100 & \\
\hline
\end{tabular}

Tabel 11 menjelaskan bahwa dari 55 orang responden dengan pendapatan $>\mathrm{UMR}$ yang tidak melakukan pencegahan sebanyak 33 orang $(60 \%)$ dan yang melakukan pencegahan sebanyak 22 orang (40\%). Responden dengan pendapatan $<$ UMR dari 45 orang responden yang tidak melakukan pencegahan sebanyak 24 orang $(53,3 \%)$ dan yang melakukan pencegahan sebanyak 21 orang (46,7\%).Hasil uji statistik Chi Square didapatkan $p$ value=0,641 yang berarti Ho gagal ditolak dan dapat disimpulkan bahwa tidak ada hubungan yang signifikan antara ekonomi dengan perilaku pencegahan HIV/AIDS.

Tabel 12

Hubungan lama menikah dengan perilaku pencegahan HIV/AIDS

$\begin{array}{ccc}\text { Lama } & \text { Perilaku pencegahan } & \text { Total }\end{array}$




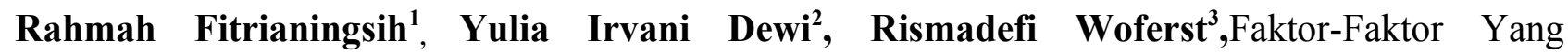
Mempengaruhi Perilaku Pencegahan HIV/AIDS Pada Ibu Rumah Tangga

\begin{tabular}{lccccccc}
\hline \multirow{2}{*}{ menikah } & \multicolumn{2}{c}{$\begin{array}{c}\text { Melaku } \\
\text { kan }\end{array}$} & \multicolumn{2}{c}{$\begin{array}{c}\text { Tidak } \\
\text { melaku } \\
\text { kan }\end{array}$} & & \multirow{2}{*}{ value } \\
\cline { 2 - 6 } & $\mathrm{n}$ & $\%$ & $\mathrm{n}$ & $\%$ & $\mathrm{n}$ & $\%$ & \\
\hline $\begin{array}{l}\text { Pernikahan } \\
\text { awal }\end{array}$ & 1 & 33,3 & 34 & 66,7 & 51 & 100 & \\
$\begin{array}{l}\text { Pernikahan } \\
\text { menengah }\end{array}$ & 21 & 47,7 & 23 & 52,3 & 44 & 100 & \multirow{2}{*}{0,275} \\
$\begin{array}{l}\text { Pernikahan } \\
\text { tua }\end{array}$ & 5 & 100 & 0 & 0 & 5 & 100 & \\
\hline Total & 43 & 43 & 57 & 57 & 100 & 100 & \\
\hline
\end{tabular}

Tabel 12 menjelaskan dari 51 responden dengan pernikahan awal yang tidak melakukan pencegahan sebanyak 34 orang $(66,7 \%)$ dan yang melakukan pencegahan sebanyak 17 orang (33,3\%). Responden dengan pernikahan menengah dari 44 orang yang tidak melakukan pencegahan sebanyak 23 orang $(52,3 \%)$ dan yang melakukan pencegahan sebanyak 21 orang (47,7\%). Responden dengan pernikahan tua yang melakukan pencegahan sebanyak 5 orang (100\%). Hasil uji statistik Chi Square didapatkan $p$ value=0,275 yang berarti Ho gagal ditolak dan dapat disimpulkan bahwa tidak ada hubungan yang signifikan antara lama menikah dengan perilaku pencegahan HIV/AIDS.

\section{PEMBAHASAN}

\section{Analisa Univariat}

\section{Usia}

Karakteristik responden menurut umur dengan kelompok umur terbanyak adalah dewasa awal (26-35 tahun) sebanyak 37 orang responden $(37 \%)$. Hasil ini sama dengan penelitian Abubakar (2015) yang menyatakan bahwa IRT yang berusia 25-49 tahun berminat dalam melakukan tes HIV/AIDS untuk mencegah penularan HIV/AIDS. Hasil penelitian ini sesuai dengan penelitian Kambu
(2012) yang menjelaskan bahwa infeksi HIV di Sorong lebih banyak terjadi pada umur muda (12-35 tahun). Hasil penelitian Stine (2011) menjelaskan bahwa tindakan pencegahan HIV/AIDS sebagai besar dilakukan oleh responden yang berusia 26-35 tahun, hal ini dikarenakan usia tersebut adalah usia subur dan seksual aktif.

\section{Agama}

Hasil penelitian didapatkan responden terbanyak adalah beragama Islam sebanyak 94 orang responden (94\%), beragama Kristen Protestan sebanyak 4 responden (4\%) dan beragama Katolik sebanyak 2 responden (2\%). Agama juga mempunyai pengaruh terhadap perilaku pencegahan HIV/AIDS. Hasil Muzakarah Nasional MUI tentang HIV/AIDS menyimpulkan bahwa penyebab penyakit HIV/AIDS sebagian besar diakibatkan oleh perilaku seksual yang diharamkan Islam, maka cara dan upaya yang paling efektif untuk mencegahnya adalah dengan melarang perzinaan serta hal-hal lain yang terkait dengan perzinaan, seperti pornografi dan pornoaksi. Penelitian ini sesuai dengan penelitian Mbonu et al (2009) bahwa agama mempunyai peran ganda terkait dengan penyakit HIV/AIDS yaitu mendukung dan merugikan. Peran yang merugikan adalah beberapa pemuka agama menghubungkan bahwa penyakit tersebut berkaitan dengan perilaku yang tidak bermoral dan dampak dari perbuatan dosa yang telah diperbuat. Sedangkan peran yang mendukung yaitu bahwa Allah, SWT memberikan kesempatan 
bagi pemeluknya untuk bertaubat meskipun telah berbuat dosa, dan jika bersungguhsungguh maka dosa-dosa yang telah diperbuat akan diampuni dan mendapatkan tempat yang lebih baik setelah kematian.

\section{Pekerjaan suami}

Hasil penelitian didapatkan karakteristik responden mayoritas pekerjaan adalah wiraswasta sebanyak 46 responden (46\%). Berdasarkan data dari Kecamatan Tenayan Raya tahun 2016 sebagian besar bekerja wiraswasta, dimana responden bekerja sebagai pekerja pembuat batu bata, petani, pedagang dan buruh. Pekerjaan suami merupakan tanggung jawab keluarga untuk memenuhi kebutuhan sehari-hari.

Hal ini sesuai dengan data dari Dinas Kesehatan Kota Pekanbaru (2016) menjelaskan bahwa pekerja wiraswasta beresiko tinggi terkena HIV/AIDS, karena wiraswasta memilki kesempatan lebih besar dibanding kelompok pekerjaan lain dalam berinteraksi langsung dengan kelompok resiko tinggi.

\section{Pemeriksaan HIV/AIDS istri}

Hasil penelitian didapatkan karakteristik responden yang tidak melakukan pemeriksaan HIV/AIDS sebanyak 88 responden (88\%) dan responden yang melakukan pemeriksaan HIV/ AIDS sebanyak 12 responden (12\%) dengan hasil pemeriksaan semua negatif (100\%). Hasil penelitian ini sesuai dengan penelitian Hariyanti (2015) yang menyatakan minat IRT dalam melakukan tes VCT masih rendah, hal ini dikarenakan IRT takut melakukan tes jika nanti hasil tes menunjukkan positif HIV/AIDS dan beranggapan bahwa mereka akan dikucilkan oleh masyarakat.

\section{Pemeriksaan HIV/AIDS suami}

Hasil penelitian didapatkan karakteristik responden yang tidak melakukan pemeriksaan HIV/AIDS sebanyak 95 orang (95\%) dan responden yang melakukan pemeriksaan HIV/ AIDS sebanyak 5 responden (5\%) dengan hasil pemeriksaan 1 responden positif terkena HIV/AIDS dan 4 responden hasilnya negatif. Sebanyak 95 responden (95\%) lainnya tidak pernah melakukan pemeriksaan tes HIV/AIDS.

Menurut Anastasya (2008) kerentanan laki-laki terhadap infeksi HIV/AIDS disebabkan oleh perilaku negatif yang dilakukan seperti membeli jasa seks komersial, pemakaian jarum suntik narkoba, suami mempunyai aktivitas yang banyak di luar rumah dan jauh dari pasangan. Hal ini berbeda dengan penelitian Umam, Dewi dan Elita (2015) yang menjelaskan laki-laki yang mengikuti pelayanan VCT lebih banyak dibandingkan perempuan.

\section{Analisis Bivariat}

\section{Hubungan pengetahuan dengan perilaku pencegahanpenularan HIV/AIDS}

Berdasarkan uji statistik menunjukkan bahwa $p$ value 0,023 , artinya terdapat hubungan antara pengetahuan dengan perilaku pencegahan penularan HIV/AIDS pada IRT.

Hasil penelitian ini sesuai dengan penelitian Prasetya (2016) yang memiliki pengetahuan baik melakukan VCT dengan $p$ 
Rahmah Fitrianingsih ${ }^{1}$, Yulia Irvani Dewi ${ }^{2}$, Rismadefi Woferst ${ }^{3}$,Faktor-Faktor Yang Mempengaruhi Perilaku Pencegahan HIV/AIDS Pada Ibu Rumah Tangga

value $=0,004$ yang dapat disimpulkan ada hubungan antara pengetahuan dengan keiginan VCT IRT di wilayah Kecamatan Kartasura. Hal yang sama juga dijelaskan oleh Wulandari, Dewi dan Darwin (2012) yang menyebutkan 88 orang $(51,8 \%)$ memiliki pengetahuan tinggi tentang pencegahan HIV/AIDS pada IRT RW 5 Kelurahan Meranti Pandak.

Pengetahuan tentang HIV/AIDS membuat seseorang memahami bagaimana penyakit tersebut menyebar dan strategi untuk melindungi diri. Pengetahuan dapat diperoleh dari pengalaman langsung ataupun melalui pengalaman orang lain. Pengetahuan dapat ditingkatkan melalui penyuluhan baik secara individu maupun kelompok untuk meningkatkan pengetahuan kesehatan yang bertujuan untuk tercapainya perubahan perilaku individu, keluarga, dan masyarakat dalam upaya mewujudkan derajat kesehatan optimal. Hal ini menunjukan bahwa tingkat pengetahuan seseorang baik mengenai HIV/AIDS tidak secara otomatis akan berbuat positif terhadap pencegahan penyebaran penyakit tersebut, sebaliknya pengetahuan yang rendah atau kurang mengenai HIV/AIDS belum tentu akan berbuat hal yang negatif (Helweg-Larsen \& Collin dalam Wulandari, Dewi \& Darwin, 2012); Notoatmodjo, 2010).

\section{Hubungan pendidikan dengan perilaku pencegahan penularan HIV/AIDS}

Berdasarkan hasil uji statistik terdapat hubungan antara pendidikan dengan perilaku pencegahan penularan HIV/AIDS pada IRT dengan $p$ value $=0,004$. Penelitian ini sesuai dengan penelitian Tasa, Ludsi dan Paun (2016) menyatakan pendidikan IRT dalam pemanfaatan VCT masih rendah dengan $p$ value 0,040. Salah satu penyebab IRT rentan terinfeksi HIV/AIDS adalah rendahnya pendidikan dan tidak memiliki pengetahuan yang cukup mengenai kesehatan (Dalimoenthe, 2011).

Hal yang sama juga dijelaskan oleh Oktarina, Hanafi dan Budisuar (2009), bahwa perempuan yang mempunyai tingkat pendidikan tinggi cenderung mempunyai pengetahuan yang lebih baik, begitu pula sebaliknya. Pendidikan sangat berpengaruh dalam melakukan mencegahan karena semakin tinggi pendidikan seseorang semakin banyak persentase yang mengetahui pengetahuan HIV/ AIDS. Semakin tinggi pendidikan semakin banyak kemudahan atau akses memperoleh informasi dan pola berpikir rasional lebih mudah dipahami (Pratiwi \& Basuki, 2011).

\section{Hubungan sikap dengan perilaku pencegahanpenularan HIV/AIDS}

Berdasarkan hasil uji statistik menunjukkan tidak ada hubungan antara sikap dengan perilaku pencegahan penularan HIV/AIDS pada IRT dengan $p$ value $=0,199$. Sebagian besar responden memiliki sikap negatif dan tidak melakukan perilaku pencegahan HIV/AIDS pada IRT yakni sebanyak 30 responden $(33,6 \%)$.

Hal ini sesuai dengan penelitian yang dilakukan oleh Kristawansari mengatakan bahwa 66 orang $(94,3 \%)$ 
mempunyai perilaku pencegahan yang kurang. Penelitian Abhinaja dan Astuti (2013) mengatakan IRT dalam perilaku pencegahan mempunyai sikap sedang $(67,8 \%)$. Demikian juga dengan penelitian Octavianty, Rahayu, Rahman dan Rosadi (2015) yang menjelaskan bahwa sebagian besar sikap IRT terhadap upaya pencegahan HIV/AIDS tergolong rendah $\mathrm{p}$ value 0,539 .

\section{Hubungan ekonomi dengan perilaku pencegahanpenularan HIV/AIDS}

Berdasarkan hasil uji statistik menunjukkan bahwa tidak ada hubungan antara ekonomi dengan perilaku pencegahan HIV/AIDS pada IRT dengan $p$ value $=0,641$. Sebagian responden memilki ekonomi $>$ UMR dan tidak melakukan perilaku pencegahan HIV/AIDS pada IRT sebanyak 33 orang $(31,4 \%)$.

Hal ini sesuai dengan penelitian Anggraeni (2013) yang menyatakan bahwa pendapatan keluarga memilki peran penting dalam mendorong istri menuju pelayanan kesehatan untuk melakukan pencegahan HIV/ AIDS. Menurut Kementerian Pemberdayaan Perempuan (2008) tentang pemberdayaan perempuan dalam pencegahan penyebaran HIV/AIDS menyatakan ketergantungan ekonomi perempuan menyebabkan perempuan sulit untuk mengontrol agar dirinya tidak terinfeksi HIV/AIDS, karena dirinya tidak bisa menolak berhubungan atau meminta suaminya mengenakan alat pelindung (kondom). Kemiskinan sering kali menyeret perempuan untuk melakukan pekerjaan yang beresiko, contohnya penjaja seks. Ketika sumber daya ekonomi terputus dari laki-laki yang dalam banyak kultur, diteguhkan sebagai kepala keluarga, membuat semakin banyak perempuan yang terpaksa melakukan transaksi seks untuk mempertahankan hidup keluarganya. Penelitian ini juga sama dengan penelitian Tasa, Ludsi dan Paun (2016) yang menyatakan pendapatan keluarga sangat berpengaruh terhadap pemanfaatan VCT dalam mencegah penularan HIV/AIDS dengan $P$ value 0,037.

\section{Hubungan lama menikah dengan perilaku pencegahan penularan HIV/AIDS}

Berdasarkan hasil analisis, sebagian besar responden pernikahan awal sebanyak 34 responden $(29,1 \%)$ tidak melakukan perilaku pencegahan HIV/AIDS pada IRT. Hasil uji statistik menunjukkan bahwa $p$ value $=0,275$ artinya tidak ada hubungan antara lama menikah dengan perilaku pencegahan penularan HIV/AIDS pada IRT. Menurut Rahayuningsih (2015) menyatakan lama menikah berhubungan signifikan dengan pengetahuan ibu tentang HIV/AIDS dengan $p=0,002$. Dalam sebuah pernikahan masalah kesehatan adalah masalah yang penting, karena dalam kehidupan rumah tangga dibutuhkan keadaan fisiologik yang sehat dan baik.

\section{SIMPULAN}

Berdasarkan hasil penelitian yang dilakukan terhadap 100 responden IRT yang 


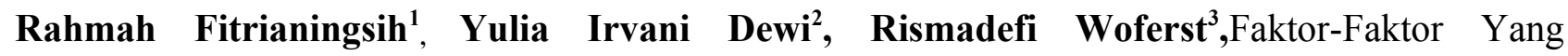
Mempengaruhi Perilaku Pencegahan HIV/AIDS Pada Ibu Rumah Tangga

berada di wilayah kerja Puskesmas Tenyan

Raya pada bulan Mei 2017 sampai Juni 2017,

disimpulkan rentang usia dewasa awal (26-35

tahun) (37\%), beragama Islam (94\%),

pekerjaan suami wiraswasta $(46 \%)$, istri yang

melakukan pemeriksaan HIV/AIDS (12\%)

dengan hasil 100 responden negatif terkena

HIV/AIDS, waktu pemeriksaan terbanyak pada tahun 2012 sebanyak (5\%), suami yang melakukan pemeriksaan HIV/AIDS (5\%) dan didapatkan tidak melakukan pemeriksaan HIV/ AIDS (95\%), dengan hasil 99 responden negatif terkena HIV/AIDS, sebagian waktu pemeriksaan terbanyak pada tahun 2012 (2\%). Berdasarkan gambaran variabel penelitian, tingkat pengetahuan baik (47\%), sikap negatif (59\%), pernikahan awal (51\%) dan ekonomi > $(55 \%)$.

Berdasarkan uji statistik dapat disimpulkan ada hubungan yang signifikan antara pengetahuan ( $p$ value $=0,023)$ dan pendidikan $(p$ value $=0,004)$ terhadap perilaku pencegahan HIV/AIDS. Faktor yang tidak berhubungan terhadap perilaku pencegahan HIV/AIDS adalah sikap ( $p$ value $=0,199)$, lama menikah ( $p$ value $=0,275)$, dan ekonomi ( $p$ value $=0,641)$.

\section{SARAN}

Hasil penelitian ini dapat dilanjutkan lebih spesifik lagi dengan menghubungkan variabel-variabel lainnya yang tidak berhubungan dalam penelitian ini. Peneliti selanjutnya juga bisa menambahkan variabel lain tentang faktor-faktor yang mempengaruhi perilaku pencegahan HIV/AIDS pada IRT.

\section{DAFTAR PUSTAKA}

Abhinaja \& Astuti. (2013). Pengetahuan sikap ibu rumah tangga mengenai infeksi menular seksual termasuk HIV/AIDS. Serta perilaku pencegahannya dikelurahan Sanur, Kecamatan Denpasar Selatan Kota Denpasar. Community health. Vol 1, No 3

Anastasya, G. (2008). Karakteristik penderita HIV/AIDS di pusat pelayanan khusus (pusyansus) klinik voluntary counseling and testing (VCT) RSUP H. Adam Malik Medan tahun 2006-2007. Medan: USU Digital Library. Diperoleh tanggal 29 Januari 2015

Anggraeni. (2013). Determinan sikap pencegahan HIV pada istri di lingkungan TNI AL di Surabaya. Diperoleh Juli dari http://digilib.unmuhjember.ac.id/downlo ad.php? $i d=2642$

Dalimonthe, I. (2011). Perempuan dalam cengkeraman HIV/AIDS: Kajian sosiologi feminis perempuan Ibu Rumah Tangga. Diperoleh tanggal 15 Februari 2017. http:// perpus. upstegal.ac.id/ /files/e book/01170414.pdf

Dewi, Y.I \& Nauli, F.A. (2016). Prevention HIV/AIDS by women in Pekanbaru Riau Province. Research Report.

Dinas Kesehatan Kota Pekanbaru. (2016). Laporan kasus HIV-AIDS tahun 2016 kota pekanbaru. Bidang $\mathrm{P} 2 \mathrm{~K}$

Direktorat Jenderal PP \& PL Kementrian Kesehatan RI. (2016). Laporan Situasi Perkembangan HIV/AIDS di Indonesia s.d Maret 2016. Jakarta

Hariyanti, R. (2015). Hubungan stigma HIV/AIDS pada ibu rumah tangga dengan minta melakukan voluntary counselling and testing HIV/AIDS di Kelurahan Kricak Tegalrejo. Diperoleh Juni dari opac.unisayogya.ac.id/730/1/ NASKAH\%20PUBLIKASI\%20RENI $\% 20 P D F . p d f$

Kambu. (2012). Analisis faktor-faktor yang mempangaruhi tindakan pencegahan penilaran HIV oleh ODHA di Sorong. 
Diperoleh Juli dari lib.ui.ac.id/file?file= digital/20298197-T30126-Analisis\%20 faktor-faktor.pdf

Kementerian Negara Pemberdayaan Perempuan RI. (2008). Pemberdayaan Perempuan dalam Pencegahan Penyebaran HIV dan AIDS. J1 Merdeka Barat No. 15 Jakarta 10110. Diakses: 15 Mei 2015. Dari http://kemenpppa.go.id / phocadownload/pedoman\%20has \%202008.pdf

Kristawansari. (2013). Hubungan antara pengetahuan dan sikap supir truk dengan perilaku pencegahan HIV/AIDS (Studi kasus di area pangkalan truk alas roban) Skripsi. Universitas Negeri Semarang

Mbonu, N. C., Van Den Borne, B., \& De vries, N. K. (2009). Stigma of people with HIV and AIDS in subsaharan Africa: A Literature Review. Trop Med Journal. Volume 14 (2) pp 110-114.

Notoatmodjo, S. (2010). Pendidikan dan perilaku kesehatan. Jakarta: Rineka Cipta.

Octavianty., Rahayu., Rahman \& Rosadi. (2015). Pengetahuan, sikap dan pencegahan HIV/AIDS pada ibu rumah tangga. Jurnal Kemas 11 (1): 53-58

Oktarina., Hanafi., \& Budisuari. (2009). Hubungan antara karekteristik responden keadaan wilayah dengan pengetahuan sikap terhadap HIV/AIDS pada masyarakat Indonesia. Penelitian sistem kesehatan. volume 12, No 4. Februari 2017

Rahayuningsih. (2015). Pengetahuan ibu hamil trimester III tentang perawatan nifas dan bayi baru lahir. Diperoleh Juli dari https://publikasiilmiah.ums.ac.id

Stine, G.J. (2011). AIDS Update 2011. New York: McGrow-Hill.

Superi. (2013). Persepsi ibu rumah tangga tentang HIV/AIDS di Desa Kori Kecamatan Sawoo Kabupaten Ponorogo. Diperoleh Februari 2017 http://lib. umpo. ac.id

Tasa, Ludji \& Paun. (2016). Pemanfaatan voluntary counseling and testing oleh ibu rumah tangga terinfeksi human immunodeficiency virus. Diperoleh Juli darihttps://www.neliti.com/id/ publications/25476/pemanfaatan- voluntary-counseling-and-testing-olehibu-rumah-tangga-terinfeksi-hiv

WHO. (2015). Global summary of the AIDS epidemic. Diperoleh tanggal 20 Januari 2017 dari http://www.who.in/hiv/datal 2015 global summary.png

WHO. (2016). Prevention of HIV/AIDS. Diperoleh tanggal 21 Januari 2017 dari http://www.who.int/mediacentre/factshee ts/fs360/en/

Wulandari., Dewi.Y.I., \& Karim, D. (2013). Hubungan tingkat pengetahuan terhadap upaya pencegahan HIV/AIDS pada ibu rumah tangga di RW 5 kelurahan meranti pandak. Jurnal online mahasiswa. JOM. Februari 2017 dari http://repository.

unri.ac.id/xmlui/handle/123456789/4209 ?show $=$ full

Umam, H., Dewi, Y.I., \& Elita, V. (2015). Identifikasi karakteristik orang resiko tinggi HIV dan AIDS untuk mengikuti program voluntary couseling and testing (VCT). Jurnal online mahasiswa. JOM. Vol 2, No 1. Februari 2017 dari https://jom.unri.ac.id/index.php/JOMPSI $\underline{\mathrm{K} / \text { issue/view/327 }}$

UNAIDS. (2013). Report on the global AIDS epidemic. Diperoleh tanggal 20 Januari 2017darihttp://www.unaids.org/en/medi a/unaids/contentassets/documents/ epidemiology/2013/gr2012/ JC2434_WorldAIDSday_results en.pdf 